\footnotetext{
${ }^{1}$ University of Warmia and Mazury in Olsztyn, Faculty of Animal Bioengineering, Poland

${ }^{2}$ Warsaw Agricultural University, Faculty of Animal Science, Poland
}

\title{
Composition and properties of meat of Pomeranian purebred lambs and their crossbreeds with Berrichon du Cher and Charolaise
}

\begin{abstract}
The quality characteristics of meat from 50-day-old Pomeranian lambs (PP) and crossbreeds by Berrichon du Cher (PB) and Charolaise (PCH) rams were determined in the study. Samples of the quadriceps muscle of the tight (m. quadriceps femoris) were taken to determine the chemical composition, physicochemical and healthful properties of meat, such as energy value, concentrations of cholesterol and collagen and the fatty acid profile in intramuscular fat. A sensory evaluation of lamb and texture measurement were also performed.

It was found that both sire breeds had a significant effect on meat quality. Meat from crossbreds contained more dry matter and protein, and was characterized by a more desirable W/P ratio, a lower calorific value, a lower collagen content and better texture parameters. Crossing had no considerable influence on the fatty acid composition in intramuscular fat, but caused changes in the cholesterol content of meat, which decreased in PB lambs and increased in PCH lambs. Taking into account the health benefits and culinary values of lamb, Berrichon du Cher is a preferred sire breed.
\end{abstract}

Key Words: crossbreeding, lambs, meat, fatty acids, cholesterol, collagen, texture

\section{Zusammenfassung}

Titel der Arbeit: Zusammensetzung und Eigenschaften des Fleisches sowohl von Lämmern des Pommerschen Schafes als auch von Kreuzungslämmern, deren Vatertiere den Rassen Berrichon du Cher und Charolaise angehören

Es wurden ausgewählte Qualitätsmerkmale des Fleisches von 50-Tage alten Lämmern des Pommerschen Schafes (PP) und ihrer Kreuzungen aus den Rassen Berrichon du Cher (PB) und Charolaise (PCH) bewertet. Bei den aus dem vierköpfigen Kniegelenksstrecker ( $m$. Quadriceps femoris) entnommenen Proben wurden die chemische Grundzusammensetzung und die physikalisch-chemischen Eigenschaften, die Parameter der Gesundheitsqualiät - der Energiewert, der Cholesterol- und Kollagengehalt und das Profil der Fettsäuren des intramuskulären Fettes ermittelt. Ebenfalls erfolgte eine sensorische Fleischbewertung und die Abmessungen der Fleischtextur wurden untersucht.

Wesentliche Änderungen der Fleischqualität in Bezug auf den Einfluss dieser beiden Bockrassen konnten beobachtet werden. Das Fleisch der Kreuzungslämmer hat sich durch eine höhere Trockenmasse und einen höheren Eiweißgehalt ausgezeichnet. Es wies sowohl ein besseres Verhältnis von W:P (Wasser : Protein) als auch einen niedrigeren Kalorien- und Kollagengehalt auf und verfügte über bessere Texturparameter. Die Kreuzung übte keinen wesentlichen Einfluss auf das Profil der Fettsäuren des intramuskulären Fettes aus, verursachte jedoch die Änderung des Cholesterolspiegels im Fleisch: Eine Senkung bei den Lämmern PB und eine Steigerung bei den Lämmern PCH.

In Hinblick auf die Gesundheitsqualität und die Kocheigenschaften des Fleisches ist die Kreuzungsvariante, bei der Böcke der Rassen Berrichon du Cher eingesetzt wurden, zu bevorzugen.

Schlüsselwörter: Kreuzung, Lämmer, Fleisch, Fettsäuren, Cholesterol, Kollagen, Textur

\section{Introduction}

Lamb has been gaining wide recognition recently. This low-calorie, easily digestible meat of a high nutritive value and unique culinary properties (ENDER et al., 1997; BRZOSTOWSKI et al., 2001; PFEUFFER, 2001; KŁOBUKOWSKI et al., 2002; 
HOFFMAN et al., 2003) meets consumer expectations. Lamb is also rich in vitamins, minerals, essential amino acids (BRZOSTOWSKI et al., 2004) and biologically active components, e.g. conjugated linoleic acid (CLA), carnitine and orotic acids (PATKOWSKA-SOKOŁA et al., 2004). In addition, lamb has a desirable fatty acid composition (HEYLEN et al., 1998). The health benefits of meat from lambs are related primarily to the diet (LEIBETSEDER, 1996; NUERNBERG et al., 2001; SZUMACHER-STRABEL et al., 2001; SANTOS-SILVA et al., 2002; GRUSZECKI et al., 2004), followed by the genotype and proper sire breed selection (ENDER et al., 1997; KLEWIEC et al., 2000; SUESS et al., 2000; LIPECKA et al., 2001 a, b; BORYS et al., 2003; HOFFMAN et al., 2003).

The aim of the present study was to determine the quality and sensory characteristics and texture parameters of meat obtained from Pomeranian lambs and crossbreeds of Pomeranian ewes with Berrichon du Cher and Charolaise rams. The Pomeranian sheep is a local meat breed in Poland distinguished by high resistance on the environmental conditions and low feeding requirements. These sheep are medium-early maturing and their meat is reported to be very good tasting.

\section{Materials and Methods}

The experiment was performed on 50-day-old single purebreed Pomeranian ram lambs (PP) and $F_{1}$ crossbreeds by Berrichon du Cher (PB) and Charolaise (PCH) rams, 12 in a group. In each group there was offspring coming from the one ram among used to mate. They were fed according to Polish standards for breeding lambs (RYŚ, 1998), in the same way in all groups. Apart from mother's milk, they were given meadow hay, maize silage and concentrate mixture for calves and lambs CJ. All the ram lambs characterized themselves similar body mass before slaughter.

After slaughter and carcass chilling, samples of quadriceps femoris were taken for quality analysis. The following determinations were made: dry matter - by sample drying at $105^{\circ} \mathrm{C}$; crude protein - by the Kjeldahl method; crude fat - by the Soxhlet method; crude ash - by sample incineration at $550^{\circ} \mathrm{C}$; $\mathrm{pH}$ - 48 hours after slaughter, with a Radiometr PHM 22 pH-meter; color - with a Specol spectrocolorimeter with an R 045 remission attachment at a wavelength of $560 \mathrm{~nm}$; water-holding capacity - by the GRAU and HAMM method (1953); fatty acid composition in intramuscular fat by esterification (PEISKER, 1964) followed by gas chromatography with a PYE Unicam chromatograph, series 104 with flame-ionization detection, on a glass column (length $2.1 \mathrm{~m}$, inner diameter $4 \mathrm{~mm}$ ) (ŻEGLARSKA et al., 1979); gross energy - with a KL 10 adiabatic bomb calorimeter; cholesterol - by the method proposed by KOMPRDA et al. (2000) with an EPOLL 200 colorimeter; collagen - by the BLOMFIELD and FARRAR method (1964).

A sensory evaluation of meat was preceded by thermal treatment, as described by BARYŁKO-PIKIELNA (1975). A five-point scale was applied, taking into account the following quality attributes of cooked meat: tenderness, juiciness, aroma (intensity and desirability) and taste (intensity and desirability). The sensory evaluation of meat samples was always conducted by the same testing panel consisting of five experienced people in the field.

Instrumental measurement of raw meat texture was performed at $18^{\circ} \mathrm{C}$, using a universal testing machine (Instron UTM 4301) with Instron software, IX Series, ver. 8.04. A shear test (CIERACH and MAJEWSKA, 1997) and a double compression test 
(TPA) were conducted to $50 \%$ sample strain, at a load of 0-1000 $\mathrm{N}$ and the speed of a measuring element (knife or compression die) of $50 \mathrm{~mm} / \mathrm{min}$. (BOURNE, 1978; CIERACH et al., 2000). The TPA test was performed on $10 \mathrm{~cm} \times 15 \mathrm{~cm} \times 15 \mathrm{~mm}$ samples, using a compression die (type 2830-011). The following texture parameters were determined: toughness I $\left(\mathrm{T}_{1)}\right.$ - maximum force $\left(\mathrm{F}_{1}\right)$ required for the first compression; toughness II $\left(\mathrm{T}_{2}\right)$ - maximum force $\left(\mathrm{F}_{2}\right)$ required for the second compression; cohesion (S) - ratio of the positive force area during the second compression over that in the first compression; elasticity (E) - increment in sample height after the first compression; gumminess $(\mathrm{G})$ - product of $\mathrm{T}_{1}$ and $\mathrm{S}$; chewiness $(\mathrm{P})$ - product of $\mathrm{T}_{1}, \mathrm{~S}$ and $\mathrm{E}$. The shear test was performed on $10 \mathrm{~cm} \times 10 \mathrm{~cm} \times 20 \mathrm{~mm}$ samples, using a single-knife shear element (Werner-Bratzler, type 2830-013). The maximum shear force $\left(F_{\max }\right)$ and energy $\left(E_{\max }\right)$ were determined.

The results were analysed statistically with Statistica 6.0 packet, using ANOVA procedure in a one-factor orthogonal design and Duncan test.

\section{Results}

A comparison of the chemical composition of meat from PP lambs and crossbreeds (Table 1) shows that it was considerably affected by sire breed.

Table 1

Quality characteristics of ram lambs (Fleischqualitätsmerkmale der Bocklämmer)

\begin{tabular}{|c|c|c|c|}
\hline \multirow{3}{*}{ Traits } & \multicolumn{3}{|c|}{ Group } \\
\hline & Pomeranian & $\begin{array}{c}\text { Berrichon du cher } \delta \\
\text { x Pomeranian }+\end{array}$ & $\begin{array}{c}\text { Charolaise } \delta^{\wedge} \\
\text { x Pomeranian } q \\
\end{array}$ \\
\hline & $\bar{x} \pm \mathrm{s}$ & $\bar{x} \pm \mathrm{s}$ & $\bar{x} \pm \mathrm{s}$ \\
\hline Dry matter (\%) & $21.22^{\mathrm{B}} \pm 0.91$ & $22.37^{\mathrm{A}} \pm 0.75$ & $22.62^{\mathrm{A}} \pm 0.61$ \\
\hline Protein (\%) & $18.12^{\mathrm{b}} \pm 0.80$ & $18.38 \pm 0.61$ & $18.78^{\mathrm{a}} \pm 0.61$ \\
\hline Fat (\%) & $1.59 \pm 0.45$ & $1.52 \pm 0.23$ & $1.48 \pm 0.51$ \\
\hline Ash (\%) & $1.11^{\mathrm{b}} \pm 0.03$ & $1.15^{\mathrm{a}} \pm 0.04$ & $1.15^{\mathrm{a}} \pm 0.05$ \\
\hline $\mathrm{pH} 48 \mathrm{~h}$ & $5.48 \pm 0.15$ & $5.46 \pm 0.11$ & $5.48 \pm 0.14$ \\
\hline W/P (water/protein) ratio & $4.36^{\mathrm{A}} \pm 0.23$ & $4.23 \pm 0.16$ & $4.12^{\mathrm{B}} \pm 0.13$ \\
\hline Color (\%) & $22.50^{\mathrm{Aa}} \pm 3.80$ & $19.73^{\mathrm{b}} \pm 1.96$ & $19.04^{\mathrm{B}} \pm 1.79$ \\
\hline Water holding capacity $\left(\mathrm{cm}^{2}\right)$ & $9.55^{\mathrm{A}} \pm 0.78$ & $8.51^{\mathrm{a}} \pm 2.03$ & $7.40^{\mathrm{Bb}} \pm 2.06$ \\
\hline Energy value (Kcal/100 g meat) & $113.02^{\mathrm{a}} \pm 6.88$ & $110.38 \pm 4.77$ & $107.18^{\mathrm{b}} \pm 7.78$ \\
\hline Cholesterol (mg/100 g meat) & $52.43^{\mathrm{A}} \pm 3.60$ & $41.57^{\mathrm{B}} \pm 2.36$ & $54.84^{\mathrm{A}} \pm 4.18$ \\
\hline Collagen (mg/100 g meat) & $236.57^{\mathrm{A}} \pm 18.41$ & $213.55^{\mathrm{B}} \pm 17.34$ & $182.34^{\mathrm{C}} \pm 24.46$ \\
\hline
\end{tabular}

A, B, C - P $\leq 0.01$

a, b $-\mathrm{P} \leq 0.05$

Meat from crossbreeds contained more dry matter $(\mathrm{P} \leq 0.01)$ and ash $(\mathrm{P} \leq 0.05)$, but was darker and had a better water-holding capacity. More significant differences were observed between meat from purebred lambs and crossbreeds by Charolaise rams. Meat from PCH lambs had a significantly higher protein concentration $(\mathrm{P} \leq 0.05)$ and a lower W/P ratio $(\mathrm{P} \leq 0.01)$.

An analysis of the healthful properties of lamb indicated distinct differences between groups in terms of calorific value and concentrations of cholesterol and collagen. Meat from crossbreeds, especially those by Charolaise sires, had a lower energy value 
$(\mathrm{P} \leq 0.05)$ and a significantly lower collagen content $(\mathrm{P} \leq 0.01)$. The cholesterol concentration was significantly lower in meat from $\mathrm{PB}$ lambs $(\mathrm{P} \leq 0.05)$ and significantly higher in meat from PCH lambs ( $\mathrm{P} \leq 0.01)$, compared with the other groups.

Crossing caused significant changes in the fatty acid composition in intramuscular fat (Table 2), i.e. a decrease in the concentrations of some saturated acids $\left(\mathrm{C}_{17: 0}\right.$ and $\mathrm{C}_{20: 0}$, in PB lambs, $\mathrm{C}_{15: 0}, \mathrm{C}_{16: 0 \text { izo }}, \mathrm{C}_{17: 0}$ and $\mathrm{C}_{20: 0}$ in PCH group) and the unsaturated acid $\mathrm{C}_{20: 1}$ in both groups of crossbreeds.

Table 2

Fatty acid composition in intramuscular fat (\%) (Zusammensetzung der Fettsäuren im intramuskulären Fett)

\begin{tabular}{|c|c|c|c|}
\hline \multirow{3}{*}{ Fatty acids } & \multicolumn{3}{|c|}{ Group } \\
\hline & Pomeranian & \begin{tabular}{|c|}
$\begin{array}{c}\text { Berrichon du cher } \\
\text { x Pomeranian } q\end{array}$ \\
\end{tabular} & $\begin{array}{c}\text { Charolaise } \hat{o} \\
\text { x Pomeranian } 9\end{array}$ \\
\hline & $\bar{x} \pm \mathrm{s}$ & $\bar{x} \pm \mathrm{s}$ & $\bar{x} \pm \mathrm{s}$ \\
\hline $\mathrm{C}_{12: 0}$ & $0.97 \pm 0.33$ & $0.88 \pm 0.20$ & $0.79 \pm 0.17$ \\
\hline $\mathrm{C}_{14: 0}$ & $6.15^{b} \pm 0.89$ & $6.67 \pm 0.52$ & $6.76^{\mathrm{a}} \pm 0.56$ \\
\hline $\mathrm{C}_{15: 0}$ & $0.78^{\mathrm{a}} \pm 0.28$ & $0.67 \pm 0.05$ & $0.63^{b} \pm 0.07$ \\
\hline $\mathrm{C}_{16: \text { izo }}$ & $0.45^{\mathrm{a}} \pm 0.20$ & $0.35 \pm 0.19$ & $0.28^{\mathrm{b}} \pm 0.12$ \\
\hline $\mathrm{C}_{16: 0}$ & $25.35 \pm 1.88$ & $26.10 \pm 1.22$ & $26.36 \pm 1.34$ \\
\hline $\mathrm{C}_{17: 0}$ & $1.24^{\mathrm{Aa}} \pm 0.16$ & $1.13^{\mathrm{b}} \pm 0.07$ & $1.08^{\mathrm{B}} \pm 0.09$ \\
\hline $\mathrm{C}_{18: 0}$ & $12.63 \pm 1.86$ & $12.17 \pm 0.88$ & $12.32 \pm 0.93$ \\
\hline $\mathrm{C}_{20: 0}$ & $0.52^{\mathrm{A}} \pm 0.24$ & $0.22^{\mathrm{B}} \pm 0.08$ & $0.29^{\mathrm{B}} \pm 0.20$ \\
\hline $\mathrm{C}_{14: 1}$ & $0.69 \pm 0.15$ & $0.68 \pm 0.09$ & $0.71 \pm 0.11$ \\
\hline $\mathrm{C}_{16: 1}$ & $4.44 \pm 0.39$ & $4.57 \pm 0.35$ & $4.79 \pm 0.28$ \\
\hline $\mathrm{C}_{17: 1}$ & $0.99 \pm 0.22$ & $0.84 \pm 0.17$ & $0.89 \pm 0.19$ \\
\hline $\mathrm{C}_{18: 1}$ & $35.51 \pm 3.06$ & $36.34 \pm 3.18$ & $35.58 \pm 1.08$ \\
\hline $\mathrm{C}_{20: 1}$ & $0.62^{\mathrm{A}} \pm 0.33$ & $0.35^{\mathrm{B}} \pm 0.09$ & $0.41^{b} \pm 0.12$ \\
\hline $\mathrm{C}_{18: 2}$ & $7.51 \pm 1.27$ & $7.05 \pm 1.02$ & $7.04 \pm 0.95$ \\
\hline $\mathrm{C}_{18: 3}$ & $0.41 \pm 0.16$ & $0.30 \pm 0.10$ & $0.32 \pm 0.15$ \\
\hline $\mathrm{C}_{20: 4}$ & $1.82 \pm 0.59$ & $1.69 \pm 0.79$ & $1.72 \pm 0.74$ \\
\hline Saturated (SFA) & $48.07 \pm 3.43$ & $48.19 \pm 2.28$ & $48.49 \pm 1.98$ \\
\hline Unsaturated (UFA) & $52.15 \pm 3.34$ & $51.81 \pm 2.28$ & $51.60 \pm 1.98$ \\
\hline Monounsaturated (MUFA) & $42.20 \pm 3.37$ & $42.77 \pm 3.71$ & $42.35 \pm 0.98$ \\
\hline Polyunsaturated (PUFA) & $9.74 \pm 1.53$ & $9.04 \pm 1.83$ & $9.08 \pm 1.75$ \\
\hline UFA : SFA & $1.09 \pm 0.15$ & $1.08 \pm 0.10$ & $1.07 \pm 0.09$ \\
\hline PUFA : MUFA & $0.23 \pm 0.05$ & $0.22 \pm 0.06$ & $0.21 \pm 0.04$ \\
\hline OFA $\left(\Sigma\right.$ SFA $\left.-\mathrm{C}_{18: 0}\right)$ & $35.44 \pm 3.18$ & $36.02 \pm 1.68$ & $36.17 \pm 1.77$ \\
\hline DFA $\left(\Sigma\right.$ UFA $\left.+C_{18: 0}\right)$ & $64.79 \pm 3.08$ & $63.98 \pm 1.68$ & $63.92 \pm 1.77$ \\
\hline DFA : OFA & $1.85 \pm 0.26$ & $1.78 \pm 0.13$ & $1.77 \pm 0.14$ \\
\hline
\end{tabular}

A, B - P $\leq 0.01$

$\mathrm{a}, \mathrm{b}-\mathrm{P} \leq 0.05$

However, the proportions between particular acid groups did not change greatly.

Meat from crossbreeds got much higher scores in an organoleptic assessment for the intensity and desirability of taste (Table 3), but the mean scores were similar in all groups. 
Table 3

Sensory evaluation and texture parameters of lamb (Sensorische Bewertung und Parameter der Fleischtextur)

\begin{tabular}{c|c|c|c}
\hline \multirow{2}{*}{ Traits } & \multicolumn{3}{|c}{ Group } \\
\cline { 2 - 4 } & Pomeranian & $\begin{array}{c}\text { Berrichon du cher } \hat{\sigma} \\
\text { x Pomeranian } \phi\end{array}$ & $\begin{array}{c}\text { Charolaise } \hat{\sigma} \\
\text { x Pomeranian } q\end{array}$ \\
\cline { 2 - 4 } & $\bar{x} \pm s$ & $\bar{x} \pm s$ & $\bar{x} \pm s$ \\
\hline
\end{tabular}

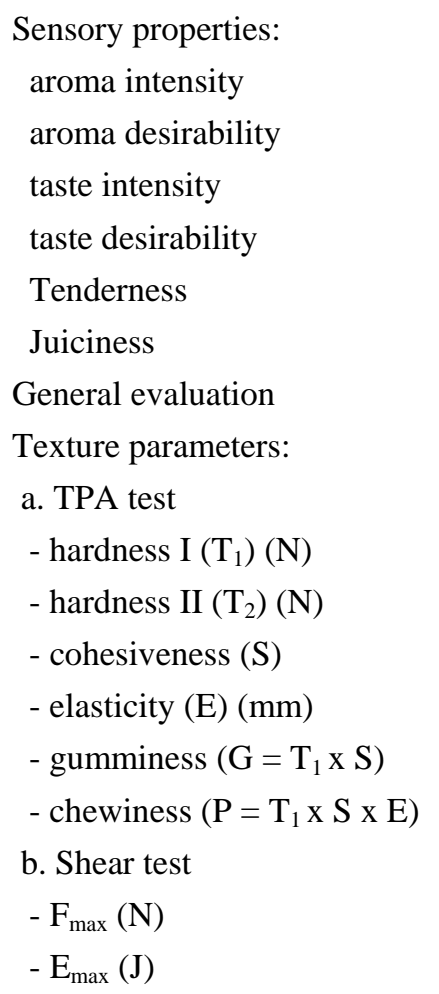

$\begin{array}{ccc}5.00 \pm 0.00 & 5.00 \pm 0.00 & 5.00 \pm 0.00 \\ 5.00 \pm 0.00 & 5.00 \pm 0.00 & 5.00 \pm 0.00 \\ 4.83 \pm 0.33 & 5.00^{\mathrm{a}} \pm 0.00 & 5.00^{\mathrm{a}} \pm 0.00 \\ 4.71^{\mathrm{Bb}} \pm 0.45 & 5.00^{\mathrm{a}} \pm 0.00 & 5.00^{\mathrm{A}} \pm 0.00 \\ 4.42 \pm 0.60 & 4.59 \pm 0.47 & 4.19 \pm 0.32 \\ 4.54 \pm 0.78 & 4.59 \pm 0.47 & 4.27 \pm 0.39 \\ 4.75 \pm 0.28 & 4.86 \pm 0.13 & 4.74 \pm 0.11\end{array}$

$\begin{array}{ccc}169.00^{\mathrm{Aa}} \pm 66.46 & 115.92^{\mathrm{B}} \pm 16.51 & 133.92^{\mathrm{b}} \pm 16.18 \\ 94.58^{\mathrm{Aa}} \pm 24.86 & 77.33^{\mathrm{B}} \pm 11.99 & 84.00^{\mathrm{b}} \pm 15.50 \\ 0.11^{\mathrm{B}} \pm 0.04 & 0.21^{\mathrm{A}} \pm 0.06 & 0.14^{\mathrm{B}} \pm 0.07 \\ 1.78^{\mathrm{b}} \pm 0.33 & 2.05^{\mathrm{a}} \pm 0.30 & 1.97 \pm 0.44 \\ 16.02^{\mathrm{b}} \pm 5.53 & 24.19^{\mathrm{A}} \pm 6.23 & 19.05 \pm 9.70 \\ 28.94^{\mathrm{B}} \pm 11.83 & 49.37^{\mathrm{A}} \pm 13.43 & 38.74 \pm 26.40 \\ & & \\ 29.57^{\mathrm{B}} \pm 0.53 & 25.15^{\mathrm{Ab}} \pm 4.73 & 25.90^{\mathrm{Aa}} \pm 2.47 \\ 0.28^{\mathrm{A}} \pm 0.05 & 0.20^{\mathrm{Bb}} \pm 0.04 & 0.24^{\mathrm{a}} \pm 0.05\end{array}$

A, B - P $\leq 0.01$

a, $\mathrm{b}-\mathrm{P} \leq 0.05$

However, meat from crossbred lambs had more desirable texture parameters. The double compression test (TPA) showed that meat from crossbreeds by Berrichon du Cher rams had the lowest level of toughness and the highest levels of cohesion, elasticity, gumminess and chewiness, compared with meat from purebreds. All these differences were confirmed by a statistical analysis. Meat from crossbreeds by Charolaise sires was also less tough than meat from Pomeranian lambs $(\mathrm{P} \leq 0.05)$, but much less cohesive $(\mathrm{P} \leq 0.01)$. Better meat texture parameters recorded in crossbreeds with the TPA test were confirmed by the shear test. It was found that meat from purebred lambs required the greatest shear force $(25.97 \mathrm{~N})$ and shear energy $(0.28 \mathrm{~N})$, followed by meat from PB and PCH lambs, but the differences between the last two groups were smaller $(\mathrm{P} \leq 0.05)$.

\section{Discussion}

Changes in the chemical and physical properties of meat from lambs, observed in consequence of crossing Pomeranian ewes with Berrichon du Cher and Charolaise rams, confirm that meat quality is determined genetically, as demonstrated by HOFFMAN et al. (2003). The better quality of meat from crossbreeds resulted from significantly higher concentrations of dry matter and protein (LEIBETSEDER et al., 
1996; SUESS et al., 2000; NUERNBERG et al., 2001). A lower W/P ratio, typical of meat from such lambs, indicates a higher degree of maturity. Particular attention should be paid to the increase in protein content, which improved both the dietary value of meat and water-holding capacity. A higher concentration of protein in meat from crossbred lambs, as well as a greater degree of its maturity, were also reported by HOFFMAN et al. (2003) and BRZOSTOWSKI et al. (2004). The darker color of meat from crossbreeds was most probably caused by changes in the chemical composition, which in turn affected light reflection. This parameter seems to be related to the dam breed as well. Other studies on lambs slaughtered at 50 days of age, where dam breeds were Polish Merino (TAŃSKI et al., 1994) or Kamieniecka (BRZOSTOWSKI et al., 1997) showed that meat from lambs of the former group was much lighter in color than meat from those of the latter group, regardless of the sire breed. Changes in the fatty acid composition in intramuscular fat, observed in the present experiment, had no considerable effect on the healthful properties of meat, because the proportions between particular groups of acids, including hypo- (DFA) and hipercholesterolemic (OFA) remained relatively unchanged. Unlike BRZOSTOWSKI et al. (2004), we found that meat from crossbred lambs had a lower calorific value, which may be related to lower fatness. The significant decrease in cholesterol level in meat from crossbreeds by Berrichon du Cher rams is certainly very positive, but the increase in cholesterol concentration in meat from crossbreeds by Charolaise sires is not dangerous, either, because lamb generally contains much less cholesterol than other kinds of meat (HASIK et al., 1999). The results of our study indicate that proper breed selection for crossing may affect the cholesterol content of meat, as reported by ARSENOS et al. (2000) and BRZOSTOWSKI et al. (2004). This concerns also collagen, a structural component of connective tissue, whose decrease may improve meat protein digestibility (BRZOSTOWSKI et al., 2004). It is also possible that apart from chemical composition this was one of the factors that determined better texture parameters of meat from crossbreeds. Changes in the texture of lamb as a result of crossing were also reported by KACZOR et al. (2000). The use of objective methods for texture parameter measurement provided a basis for a reliable estimation of the effects of sire breeds on the culinary value of meat from crossbred lambs. This confirms the opinion that a sensory evaluation and instrumental analysis complement each other and should be performed simultaneously for best results (CIERACH and MAJEWSKA, 1997).

The positive changes in meat quality prove that Pomeranian ewes can be successfully mated to both Berrichon du Cher and Charolaise rams. However, the preferred sire breed is Berrichon du Cher, due to healthful properties of meat, especially a lower cholesterol level, as well as better texture parameters.

\section{References}

ARSENOS, G.; ZYGOYJANNIS D.; KUFIDIS, D.; KATSAOUNIS, N.; STAMATARIS, C.:

The effect of breed, slaughter weight and nutritional management of cholesterol content of lamb carcasses. Small Rum. Res., 36 (2000), 275 - 283

BARYŁKO-PIKIELNA, N.:

The draft of the food sensory analysis. PWN, Warszawa (1975)

BLOMFIELD, L. J.; FARRAR, F.:

Factors affecting the determination of hydroxyproline. Anal. Chem. 20 (1964), 950 - 953

BOURNE, M. C.;

Texture profile analysis. Food Techn., 6 (1978), 62 - 66 
BORYS, B.; JARZYNOWSKA, A.; BORYS, A.:

Health quality of meat of light slaughter lambs depending on age and genotype. Zesz. Nauk. Prz. Hod., 68 (2003), 63 - 71

BRZOSTOWSKI, H.; SOWIŃSKA, J.; TAŃSKI, Z.:

The slaughter value and the quality of meat obtained from Pomeranian Sheep lambs and crossbreeds of Pomeranian ewes with meat breed rams. Pol. J. Food Nurt. Sci., vol. 3 (2001), 97 - 99

BRZOSTOWSKI, H.; TAŃSKI, Z.; MILEWSKI, S.; SOWIŃSKA, J.: Meat quality of young Kamieniecka rams and Kamieniecka cross-breeds slaughtered at the age of 50 or 100 days. J. Anim. Feed Sci., 6 (1997), 333 - 341

BRZOSTOWSKI, H.; TYWOŃCZUK, J.; TAŃSKI, Z.:

Indexes of nutritive value of meat obtained from Pomeranian lambs and crossbreeds of Pomeranian ewes with meat breed rams. Arch. Tierz., Dummerstorf 47 (2004) Special Issue, 175 - 182

CIERACH, M.; MAJEWSKA, K.:

Comparison of instrumental and sensory evaluation of texture of cured and cooked beef meat. Nahrung, 41 (1997) 6, 366 - 369

CIERACH, M.; SZPENDOWSKI, J.; SMIETANA, Z; MAJEWSKA, K.:

The influence of the additive of „no-meat” proteins on mechanical properties of sausages. Zesz. Nauk. Polit. Opols., Mechanika, 61 (2000), 73 - 78

ENDER, K.; NUERNBERG, K.; PAPSTEIN, H.-J.:

Die zwei Seiten des Fettes - eine Standortbestimmung. Arch. Tierz., Dummerstorf 40 (1997) 1, 35 - 45

GRAU, R.; HAMM, R.:

Über das Wasserbindungsvermögen des toten Säugetiermuskels. I. Mitteilung. Der Einfluss des pHWertes auf die Wasserbindung von zerkleinertem Rindermuskel. Biochem., I, (1953) 325 - 328

GRUSZECKI, T.M.; JUNKUSZEW, A.; LIPECKA, CZ.; KAMIŃSKA, A.; SZYMANOWSKA, A.; PATKOWSKI, K.:

Fatty acids composition in sheep milk and muscle tissue of lamb fed protective fat-supplemented fodder. Arch. Tierz., Dummerstorf 47 (2004) Special Issue, 183 - 188

HASIK, J.; HRYNIEWIECKI, L.; GRZYMISŁAWSKI, M.: Dietetic. Wyd. Lek. PZWL (1999)

HEYLEN, K.; SUESS, R.; FREUDENREICH, P.; LENGERKER, G. v.: Einfluss des intramuskulären Fettes auf die Qualität von Lammfleisch unter besonderer Berücksichtigung der Verzehrsqualität. Arch. Tierz., Dummerstorf 41 (1998) 1/2, 111 - 122

HOFFMAN, L. C.; MULLER, M.; CLOETE, S. W. P.; SCHMIDT, D.:

Composition of six crossbred lamb types: sensory, physical and nutritional meat quality characteristics. Meat Sci. 65 (2003), 1265 - 1274

HOLFORD, P.:

The Optimum Nutrition Bible. Świat książki, Warszawa (1999)

JANDÁSEK, J.; KOMAR, M.; MINERSKI, M.; INGR, I.:

Comparison of the contents of intramuscular amino acids in different lamb hybrids. Czech J. Anim. Sci., 48 (2003) 7, 301 - 306

KACZOR, U.; CIURUŚ, S.; PUSTKOWIA, H.:

Meat quality parameters of young rams of Polish Longwool Sheep and its crossbreeds with meat breed rams. Rocz. Nauk. Zoot., 8 (2000), 82 - 87

KLEWIEC, J.; GRUSZECKI, T.; MARKIEWICZ, J.; GABRYSZUK, M.: Slaughter evaluation of lambs maintained in alcove and pasture system. Prz. Hod., 8 (2000), 49 - 50

KŁOBUKOWSKI, J.; BRZOSTOWSKI.; H.; TAŃSKI, Z.; WIŚNIEWSKA-PANTAK, D.; SOWIŃSKA, J.; The quality and nutritive value of the meat protein of various lambs genotypes. Pol. J. Food Nutr. Sci., 11 (2002) 4, 53 - 57

KOMPRDA, T.; ZELENKA, J.; TIEFFOVÁ, P.; ŠTOHANDLOVÁ, M.; FOLTYN, J.; FAJMONOVÁ, E.; Effect of age on total lipid, cholesterol and fatty acids content in tissues of and growing chickens. Arch. Geflügelk. 64 (2000), 121 - 128

LEIBETSEDER, J.:

Beeinflussung der Zusammensetzung tierischer Fette durch die Fütterung. Arch. Tierz., Dummerstorf 39 (1996) 4, 333 - 345

LIPECKA, Cz.; GRUSZECKI, T.; KAMIŃSKA, A.; JANKUSZEW, A.:

Growth and slaughter value of hybrid lambs with suffolk and charolaise share in genotype. Pol. J. Food Nutr. Sci. 3 (2001a), 132 - 135

LIPECKA, C.; GRUSZECKI, T.; PIĘTA, M.; SZYMANOWSKA, A.; PATKOWSKI, K.; SZYMANOWSKI, M.; JUNKUSZEW, A.:

Meat performance of hybrid ram lambs with different shares of a prolific breed. Arch. Tierz., Dummerstorf 44 (2001b) Special Issue, 370 - 376

NUERNBERG, K.; GUMBACH, S.; NUERNBERG, G.; HARTUNG, M.; ZUPP, W.; ENDER, K.: 
Influence of breed and production system on meat quality and fatty acid composition in lamb muscle. Arch. Tierz., Dummerstorf 44 (2001) Special Issue, 351 - 360

PATKOWSKA-SOKOŁA, B.; BODKOWSKI, R.; CHABROM, A.:

The content of L-carnitine in products of different ruminant species. Zesz. Nauk. Prz. Hod., 72 (2004), $79-86$

PEISKER, K. V,:

A rapid semi-micro method for preparation of methyl ester from triglycerides using chloroform, methanol, sulphuric acid. J. Amer. Oil Chem. Sci., 41 (1964), 87 - 88

PFEUFFER, M.:

Physiologic effects of individual fatty acids in animal and human body, with particular attention to RYŚ, S.: coronary heat disease risk. Arch. Tierz., Dummerstorf 44 (2001) 1, 89 - 98

Feeding norms of cattle and sheep by traditional system. Inst. Zoot., Kraków (1998)

SANTOS-SILVA, J.; BESSA, R. J. B.; SANTOS-SILVA, J.:

The effect of genotype, feeding system and slaughter weight on the quality of light lambs. Livestok Production Sci., 77 (2002), 187 - 194

SUESS, R.; HYLEN, K.; LENGERKEN, G. v.:

Einfluss von Booroola-Merinos auf Fettgehalt und -qualität der Schlachtkörper bei Kreuzung mit Merinofleischschafen. Arch. Tierz., Dummerstorf 43 (2000) 1, 45 - 56

SZUMACHER-STRABEL, M.; POTKAŃSKI, A.; CIEŚLAK, A.:

Effect of protected fatty acid composition and conjugated linoleic acid level in meat and milk of sheep. Arch. Tierz., Dummerstorf 44 (2001) Special Issue, 329 - 335

TAŃSKI, Z.; BRZOSTOWSKI, H.; MILEWSKI, S., STEMPEL R.:

The influence of the slaughter age of rams lambs of the Polish Merino breed and its crossbreeds on some meat quality indices. Zesz. Nauk. Prz. Hod., 13 (1994), 251 - 258

ŻEGLARSKA, Z.; MARKIEWICZ, K.; SMOCZYŃSKI, S.:

Composition of fatty acid in muscle fat and depot fat of rabbits. Zesz. Nauk. ART Olsztyn, 15 (1979), $167-177$

Received: 2005-11-09

Accepted: 2006-06-21

Author's addresses

Prof. Dr. habil. ROMAN NIŻNIKOWSKI*

Department of Animal Breding Sheep and Goat Division

SGGW-Warsaw Agriculture University

02-876 WARSZAWA, ul. Ciszewskiego 8

POLAND

*Corresponding Author

E-Mail: roman_niznikowski@sggw.pl

Prof. Dr. habil. HENRYK BRZOSTOWSKI

Dr. habil. STANISŁAW MILEWSKI

Department of Sheep and Goat Breding

University of Warmia and Mazury in Osztyn

10-719 OLSZTYN, ul. Oczapowskiego 2

POLAND 